\title{
Teori Oligarki Winters Atas Penambangan Batubara Di Kalimantan Timur
}

\author{
Anita Febriani $^{* 1}$, Dilla Janu Istanti ${ }^{2}$, Ponco Wibowo ${ }^{3}$ \\ ${ }^{1,2,3}$ Program Studi Magister llmu Pemerintahan Fakultas Ilmu Sosial dan Ilmu Politik \\ Universitas Lampung \\ E-mail: " ${ }^{1}$ anitafebriani82@gmail.com, ${ }^{2}$ dillajanu1991@gmail.com, \\ poncowibowo100@gmail.com
}

\begin{abstract}
Abstrak
Potret Oligarki terjadi dalam proses penambangan batu bara di Kalimantan Timur. Elite pemegang kekuasaan banyak terlibat berkolaborasi menjadi rantai pengeruk sumber daya tambang di Kalimantan Timur. Film Sexi Killer karya WatchDoc Documentary memberikan gambaran jelas bagaimana para elite terlibat menjadi pemain tambang batubara di Kalimantan Timur. Penambangan batubara tak lantas mendatangkan kesejahteraan bagi masyarakat sekitar, tetapi justru membawa berbagai bencana lingkungan. Beberapa nama elite penguasa terseret dalam lingkaran praktik bisnis penambangan. Teori oligarki Jefri A. Winters mampu menjelaskan mengapa potret ini dapat terjadi. Para elite mengendalikan sumber daya material untuk meningkatkan kekayaan dan mempertahankan posisi sosialnya melalui otoritas,. Demokrasi seolah tergelincir dalam lingkaran oligarki. Para elite mengendalikan sumber daya material untuk meningkatkan kekayaan dan mempertahankan posisi sosialnya. Oligarki yang terlihat pada era Soeharto ternyata tidak lantas menghilang begitu saja. Oligarki justru berkembang dengan wujud yang berbeda. Oligarki pada masa pemerintahan Soeharto bersifat oligarki sultanisti, saat ini telah bertransformasi menjadi oligarki penguasa kolektif.
\end{abstract}

Kata Kunci-Elite, Oligarki, Penambangan Batubara Kalimantan

\begin{abstract}
Oligarchy portrait occurs in the process of coal mining in East Kalimantan. Many of the power-holding elites are involved in collaborating to become a mining resource chain in East Kalimantan. The Sexi Killer film by WatchDoc Documentary provides a clear picture of how the elite was involved in becoming coal mining players in East Kalimantan. Coal mining does not necessarily bring prosperity to the surrounding community but instead brings about various environmental disasters. Several names of the ruling elite were dragged into the circle of mining business practices. Jefri A. Winters' oligarchic theory can explain why this portrait can occur. Through authority, the elites control material resources to increase wealth and maintain their social position. Democracy seems to have slipped into an oligarchic circle. The elites control material resources to increase wealth and maintain their social position. The oligarchy seen in the Soeharto era did not just disappear. Oligarchy develops in a different form. The oligarchy during the Soeharto era was a sultanic oligarchy, now it has transformed into an oligarchy of collective rulers.
\end{abstract}

Keywords-Elite, Oligarchy, Kalimantan Coal Mining 


\section{PENDAHULUAN}

Robison dan Hadiz dalam Ananta (2014:7) menggambarkan oligarki sebagai sistem relasi kekuasaan untuk mempertahankan kekayaan. Pendapat lain menjelaskan bahwa oligarki seperti predator yang melibatkan diri dalam pertahanan dan peningkatan kekayaan melalui sejumlah bisnis yang mereka kelola. Oligarki terlihat seperti memberikan nuansa baru dan lapangan pekerjaan, namun disisi lain oligarki menyebabkan adanya kesenjangan dalam pendapatan (Zuada dkk, 2016:4).

Hidayat dkk (2018:6) menjelaskan oligarki merupakan kekuasaan sekelompok kecil yang berorientasi pada kepentingan pribadi. Sehingga oligarki dapat disimpulkan sebagai kepemilikan kekuasaan dan penggunaan kekuasaan yang sasaran utamanya bukanlah orang banyak (masyarakat) melainkan pelaku itu sendiri. Oligarki dipahami sebagai bentuk relasi kekuasaan dari koalisi politico-business untuk memperkaya diri dengan mengeruk sumber daya publik.

Potret Oligarki dapat dilihat dari proses penambangan batu bara yang ada di Kalimantan Timur. Elite pemegang kekuasaan banyak terlibat berkolaborasi menjadi rantai pengeruk sumber daya tambang di Kalimantan Timur. Hal ini secara jelas digambarkan pada film Sexi Killer karya WatchDoc Documentary. Film tersebut mampu menjelaskan bagaimana para elite penguasa menjadi pemain dalam rangkaian penambangan batu bara di Kalimantan Timur.

Koesoemadinata (2011: 33) dalam penelitiannya menjelaskan kondisi batu bara saat ini. Menurutnya saat ini batu bara masih dipilih sebagai bahan pembangkit energi dalam persentase terbesar. Batubara di seluruh dunia diperkirakan memiliki lebih dari 984 milyar ton. Batu bara diprediksi dapat memenuhi kebutuhan selama lebih dari 190 tahun. Terdapat lebih dari 70 negara memiliki cadangan batu bara terbanyak, diantaranya Amerika Serikat, Rusia, China, dan India. Indonesia sendiri memiliki cadangan batu bara dengan jumlah yang tidak kalah banyak. Direktur Jenderal Mineral dan Batubara (Minerba) Bambang Gatot Ariyono melalui laman kompas (2019) mengatakan Indonesia diprediksi memiliki cadangan batu bara hingga tahun 2100 atau sekitar 80 tahun kedepan jika diimbangi dengan tingkat produksi 400 -an juta hingga 500-an juta per tahunnya. Laman resmi Badan Tenaga Nuklir Nasional (2018) menerangkan alasan batubara begitu menjadi primadona kebutuhan di Indonesia. Hal tersebut dikarenakan penopang utama nuklir dalam pembangkitan listrik di Indonesia sudah mulai menipis, sedangkan kenaikan kebutuhan listrik mencapai 7\% dari berbagai sektor.

Diskursus batu bara berada pada puncaknya di tahun 2019. Dirkursus baru bata menjadi perbincangan menarik saat dirilisnya film "Sexy Killer" karya WatchDoc Documentary. Film ini memperlihatkan berbagai kenyataan pahit dibalik proses penambangan batu bara. Realita masyarakat yang hidup bertetangga dengan perusahaan pertambangan batu bara di Kalimantan Timur jauh dari kata sejahtera. Penambangan batu bara justru kerap mendatangkan berbagai macam bencana lingkungan bagi kehidupan masyarakat sekitar. Film Sexy Killers menyuguhkan hasil observasinya yang dilakukan pada awal Oktober tahun 2015 melalui sajian visual. Hasil temuan menunjukkan berbagai dampak negatif atas operasional penambangan batubara, mulai dari hilangnya air bersih, mata pencarian, hingga pada prenggutan jiwa masyarakat sekitar (Sexy Killers, 2019).

Peraturan Daerah Kabupaten Kutai Kartanegara nomer 79 Tahun 2013 menetapkan jarak minimal tambang dengan pemukiman ialah 500 M. Nyatanya, peraturan tersebut tak sesuai dengan kenyataan di lapangan. Jarak minimal yang ditentukan hanya sekedar angka. Pemukiman masyarakat dalam realitanya tidak memiliki batas yang tegas dengan perusahaan tambang. Pada bulan November 2018 di sanga-sanga Kabupaten Kutai Kartanegara Kalimantan Timur setidaknya menyebabkan 5 rumah hancur, 11 rumah lainnya mengalami kerusakan dan 
jalan utama amblas akibat aktivitas penambangan yang terlalu dekat dengan pemukiman dan fasilitas umum (Sexy Killers 2019, menit ke 22:11). Dampak lainnya juga terlihat pada retaknya dinding rumah warga hingga matinya sektor pertanian sebagai mata pencarian warga sekitar. Tambang batubara juga menghancurkan jalur air bersih. Hal tersebut dijelaskan dalam film Sexi Killers saat Komari memperlihatkan air keruh yang diperuntukkan untuk kebutuhan minum sehari-hari. Komari menjelaskan jauh sebelum adanya perusahaan batu bara terdapat gununggunung yang menghasilkan air jernih. Berbeda dengan saat ini, mayarakat hanya mengandalkan air hujan untuk mendapatkan akses air bersih (Sexy Killers 2019, menit ke 05:07).

Protes kerap kali dilakukakan oleh warga. Nyoman Derman, seorang warga dari desa Kerta Buana, kabupaten kutai kartenagara mengaku pernah melakukan protes dengan menghadang alat berat. Alih-alih mendapat solusi atas keadaan, dirinya justru ditangkap dan dipenjarakan selama 3 bulan dengan tuduhan mengganggu jalannya operasional perusahaan. Selama Nyoman berada di bui, perusahaan semakin leluasa untuk beroperasi hingga wajah kartabuana menjadi visual yang tandus. Ditangkapnya Nyoman juga menimbulkan efek jera bagi masyarakat lainnya. Masyarakat takut mendapatkan hukuman serupa, sehingga tidak ada lagi perlawanan yang terlihat (Sexy Killers 2019, menit ke 07:28). Menurut Nyoman, jalannya operasional perusahaan berada pada naungan pemerintah, sehingga hal tersebut menunjukkan proposional pemerintah tidak sesuai pada idealitasnya (Sexy Killers 2019, menit ke 9:35).

Ironi penambangan batu bara tidak hanya sampai disitu. Lebih tragis lagi saat lubang bekas penggalian batu bara memakan banyak korban jiwa. Pasalnya setelah selesai membuat lubang untuk mengeruk batu bara, sejumlah perusahaan cenderung meninggalkan daerah tambang begitu saja. Tambang-tambang yang sudah habis diambil batu baranya dibiarkan menganga dan belum tereklamasi hingga saat ini. Antara tahun 2011 hingga tahun 2018 tercatat setidaknya telah memakan 32 jiwa akibat tenggelam di lubang tersebut., sedangkan secara Nasional antara tahun 2014 hingga 2018 telah memakan sebesar 115 jiwa (Sexy Killers 2019, menit ke 14:27).

Gubernur Kaltim Isran Noor dalam film Sexy Killer juga telah dimintai tanggapan atas permasalahan ini. Gubernur tersebut hanya menanggapi dengan dalih sudah menjadi nasib korban ketika ditemukan meninggal berada pada kolam lubang bekas tambang batu bara. Ketika diwawancarai atas upaya pertanggung jawaban oleh narasumber pada Sexy Killer, Isran Noor hanya menjawab untuk meminta masyarakat lebih waspada. Pemerintah setempat seolah memiliki pembelaan bahwa telah disampaikannya sejumlah himbauan (Sexy Killers, 2019, menit ke 15:09).

Berdasarkan pengakuan warga, pemerintah menganggap hal tersebut hanya sebagai kasus kemalangan biasa. Padahal jika ditelisik lebih dalam, lubang bekas tambang sangat berdekatan dengan pemukiman warga, bahkan juga berada di belakang sekolah. Ketika di desak, pemerintah pernah berjanji untuk menutup lubang bekas tambang batu bara. Bukannya menimbun seperti keadaan semula, pemerintah justru hanya menutup lubang dengan dinding beberapa helai seng dengan himbauan untuk tidak mendekati lubang tersebut (Sexy Killers 2019, menit ke 14:57).

Jumlah pemakaian batubara dalam persentase terbesar didunia sebagai kebutuhan pengadaan listrik dapat memberikan keuntungan yang besar bagi pemain di dalamnya. Beberapa oknum mampu melihat keuntungan tersebut sebagai satu bisnis yang menjanjikan. Film Sexy Killer memberi bukti bahwa proses penambangan batu bara dalam realitanya tidak menghasilkan kepuasan merata. Keuntungan hanya dapat dinikmati oleh beberapa pihak, sedangkan sebagian besar masyarakat harus rela menikmati besarnya kerugian.

Beberapa studi mengenai tambang batu bara Kalimantan Timur telah dilakukan. Muhdar (2015: 14) tentang aspek hukum reklamasi pertambangan batubara pada kawasan hutan di Kalimantan 
Timur menunjukkan bahwa peraturan pemerintah kalimantan timur tidak memiliki kesesuaian dengan prinsip perlindungan hutan. Penelitian ini menunjukkan bahwa pemerintah tidak memiliki pengaturan kewajiban penambangan sejak fase perencanaan, pelaksanaan, maupun fase reklamasi.

Studi lain, Istiadi (2017:9) tentang kebijakan penetapan kuota produksi batubara di provinsi Kalimantan Timur menunjukkan belum ada petunjuk tekhnis berupa tata cara peraturan Gubernur dalam rangka peningkatan pengawasan di Kalimantan Timur. Marennu (2019:3) tentang analisis kebijakan pemerintah daerah bidang pertambangan di Kota Samarinda menemukan temuan luasan area tambang batu bara yang mencapai 4,5 hektar di Provinsi Kalimantan Timur telah terbukti menghancurkan lahan pangan bagi jutaan jiwa warga setempat. Sehingga pelaksanaan kebijakan pemerintah daerah kota samarinda belum maksimal.

Penelitian ini berbeda dengan penelitian sebelumnya, karena penulis tidak akan menitik beratkan pada analisa kebijakan operasional Batubara. Penulis akan melihat penambangan batubara di Kalimantan Timur dengan menggunakan sudut pandang teori oligarki Jeffrey A. Winters. Melalui theory ini penulis akan melihat sisi kekuasaan saling terhubung di dalamnya dan kerap digunakan untuk menguasai sumber daya alam yang ada. Teori oligarki akan membantu menjelaskan bagaimana hal itu terjadi. Penulis akan menjelaskan bagaimana penguasa bermain di dalam proyek penambangan batubara dan melakukan eksploitasi hanya untuk kepentingan segelintir elite penguasa.

\section{METODE PENELITIAN}

Penelitian ini menggunakan metode penelitian library research dengan pendekatan deskriptif analisis. Pada penelitian ini penulis mencoba menganalisis potret relasi penguasa atas penambangan batu bara di Kalimantan Timur pada film sexy killer. Analisa dalam penelitian ini menggunakan teori oligarki Jeffry A. Wintters. Analisa juga diperkuat dengan menelaah berbagai tulisan atau jurnal, dan laporan-laporan yang relevan sebagai penyajian data sekunder dalam penulisan ini.

\section{HASIL DAN PEMBAHASAN}

\subsection{Teori Oligarki Jefri A. Winters}

Jeffrey A. Winters (2011:4) merupakan pakar oligarki dan elite diberbagai kasus sejarah Athena, Roma, Eropa zaman pertengahan, Amerika Serikat, dan beberapa negara Asia Tenggara. Riset, publikasi dan pengajaraanya berfokus kepada bidang ekonomi politik komparatif dan International. Tema-tema karya Winters selain oligarki juga mencakup hubungan negara dan kapital, pergerakan kapital dan kekuasaan struktural ivenstor, hak asasi manusia, otoritarianisme dan transisi demokrasi di negara-negara pacakolonial, dan bank dunia. Winters telah melakukan penelitian ekstensif dikawasan Asia Tenggara khususnya Indonesia, Vietnam, Thailand, Filiphina, Malayasia dan Singapur.

Winters (2011:28) berpendapat oligarki termasuk salah satu konsep yang sering digunakan namun konsepnya masih begitu kurang dikembangkan dalam lingkup sosial. Jumlah literature oligarki tidak seimbang dengan jumlah kasus dalam setiap sejarah. Contohnya sangat sedikit sekali kesamaan konseptual dalam penerapan istilah oligarki Filiphina, Rusia, dan Eropa di zaman pertengahan. Makna oligarki belum begitu jelas sehingga hampir semua sistem politik atau komunitas yang belum melibatkan keikutsertaan penuh oleh anggotanya dianggap memiliki kecendrungan terhadap oligarkis. 
Menurut Winters, Teori oligarki lebih menekankan pada potret kekayaan yang terkonsentasi di tangan individu- individu tertentu. Hal tersebut dilakukan untuk memperkuat keberadaan penguasa yang kerap tidak dapat tertangkap oleh kerangka generik pluralis (Winters, 2011:16). Potret tersebut kemudian berkembang dan menghasilkan jenis politik oligarki. Teorinya juga menyoroti pada kekuasaan lain yang ada di dalam masyarakat. Menurutnya, kekayaan akan selalu berpengaruh besar terhadap kemampuan oligarki mempertahankan dan memperjuangkan kepentingan utamanya. Teori ini membuktikan bahwa demokrasi seolah telah menjadi sistem yang tidak lagi berfungsi.

Menurut Winters (2011:31) langkah pertama untuk mendefinisikan oligarki dapat menggunakan dua pendekatan. Pertama adalah dasar kekuasaan minoritas oligarki. Pengaruh minoritas oligarki didasarkan kepada konsentrasi ekstrem kekuasaan dan dibuyarkan dengan pemecahan kekuasaan tersebut secara radikal. Kedua adalah jangkauan kekuasaan minoritas oligarki. Jangkauan kekuasaan minoritas oligarki merengkuh komunitas cukup luas sehingga usaha melarikan diri darinya nyaris mustahil dan mahal sekali biayanya. Berdasarkan kedua hal tersebut, oligarki dapat didefinisikan sebagai pelaku yang menguasai dan mengendalikan konsentrasi besar sumber daya material yang bisa digunakan untuk mempertahanan dan meningkatkan kekayaan pribadi dan posisi sosial ekslusifnya.

Sejatinya oligarki berada pada setiap zaman, hanya saja terdapat beberapa tipe di dalamnya. Winters menggolongkan oligarki menjadi empat ciri utama untuk memperjelas mengenai oligarki, yaitu :

1. Keterlibatan langsung oligarki dalam pemaksaan hak atas harta dan kekayaan,

2. Keterlibatan oligarki pada kekuasaan atau pemerintahan,

3. Sifat keterlibatan dalam memaksa apakah kolektif atau terpecah,

4. dan sifat liar atau jinak (Winters 2011: 48).

Selain itu Winters (2011:52) juga merumuskan empat tipe ide oligarki, yaitu:

1. Oligarki Panglima

Oligarki panglima muncul melalui kekuasaan yang memaksa atau dengan kekerasan secara langsung. Oligarki panglima mempunyai tentara yang dijadikan sebagai senjata untuk merebut sumber daya secara langsung kekuasaan milik oligarki lainnya. Oligarki panglima merupakan pengumpulan kekayaan dilakukan dengan menaklukan satu panglima dengan panglima lain, akibatnya ancaman yang paling dominan terjadi pada klaim harta daripada pendapatan. Oligarki panglima pernah terjadi pada masa pra sejarah, Eropa zaman pertengahan dan keluarga yang berseteru di Pegunungan Apalachia.

2. Oligarki Penguasa Kolektif

Oligarki mempunyai kekuasaan serta berkuasa dengan cara kolektif melalui satu lembaga yang memiliki aturan atau norma. Dalam oligarki ini, para penguasa akan saling bekerja sama dalam mempertahankan kekayaannya dengan cara memerintah suatu komunitas. Oligarki penguasa kolektif membagi biaya kekuatan pemaksa antar yang mereka bayar dengan mereka gunakan sendiri (terutama pedesaan diluar ibukota). Mereka cenderung memerintah dan membayar aparat setengah negara secara lngsung. Oligarki penguasa kolektif merupakan oligarki pertama kali yang melibatkan banyak aspek, seperti oligarki saudagar hingga finansial kota. Tujuannya untuk menggantikan foendal tuan rumah. Oligarki penguasa kolektif bisa ditemukan pada komisi mafia, pemerintahan Yunani-Roma dan juga praktek politik pasca Soeharto di Indonesia.

3. Oligarki Sultanistik

Oligarki sultanistik terjadi ketika ada monopoli yang dijadikan sebagai sarana pemaksaan pada satu tangan Oligarki. Pada bentuk oligarki ini terdapat hubungan antara Oligark (patron-klien) dengan Oligarki yang berkuasa. Oligarki sultanistik memberikan wewenang 
dan juga kekerasan pada penguasa utama saja, sedangkan para Oligarki lainnya hanya menggantungkan pertahanan kekayaan serta harta mereka pada Oligarki utama.

\section{Oligarki Sipil}

Oligarki sipil sepenuhnya tidak bersenjata dan tidak berkuasa langsung. Oligarki sipil hanya menyerahkan kekuasaannya kepada suatu lembaga non pribadi dan juga kelembagaan yang mempunyai hukum lebih kuat. Oligarki sipil hanya fokus mempertahankan pendapatan dengan cara mengelak dari jangkauan negara dalam meredistribusi kekayaannya. Oligarki Sipil tidak selalu bersifat demokratis serta melibatkan pemilu. Hal ini terjadi di Amerika Serikat dan India di mana oligarki bersifat demokratis secara prosedural, akan tetapi di Singapura dan Malaysia oligarki bersifat otoriter.

Menurut winters jinaknya oligarki tidak berpengaruh pada keterlibatan langsung oligarki pada kekuasaan ataupun pada pelecutan senjata militer. Kadar kejinakan oligarki justru sangat dipengaruhi oleh sekuat apa sistem mengendalikan tingkah laku oligarki (winters, 2011: 55). Teori yang telah di tawarkan oleh Jeffrey A Winter dapat membantu menrefleksikan apakah kasus penambangan batu bara tergolong dalam bentuk oligarki. Teori ini juga akan memberikan gambaran bagaimana para penguasa saling terhubung dan menjadi pemain dalam eksploitasi proyek penambangan batubara di Kalimantan Timur.

\subsection{Winters, Oligarki, dan Elite Pemain Batubara}

Winters (2011:36) memisahkan kaum elite dengan oligarki. Menurut Winters kaum elite tidak sepenuhnya dapat dikatakan pelaku oligarki, namun oligarki pasti berasal dari kalangan elite. Oligarki lebih merujuk kepada politik pertahanan kekayaan material oleh pelaku dengan mendominasi minoritas lainnya. Makin besar kebutuhan oligarki mempertahankan hak miliknya, akan semakin besar pula pelaku oligarki memainkan peran kekuasaannya.

Kasus penambangan batu bara Kalimantan Timur menjerat sejumlah kaum elite ke dalam lingkaran oligarki. Fatalnya ketika kaum elite yang menjadi pemain batubara adalah mereka yang ada di ranah pemangku kekuasaan. Kekuasaan seolah menjadi senjata untuk melancarkan misi dalam proses pelaksanaan operasional tambang batu bara.

Oligarki jika dilihat kembali dengan menggunakan kategori liar dan jinaknya lingkaran oligarki Winters (2011:48), kasus penambangan batubara di Kalimantan sudah tidak lagi dapat dikategorikan sebagai oligarki jinak. Lingkaran oligarki yang bermain dalam ranah pemerintahan memperlihatkan adanya kadar oligarki yang lebih kuat (liar) atau dapat dikatakan telah berada pada level yang telah mengkhawatirkan.

Winters telah menyoroti kasus Oligarki di Indonesia sejak lama. Menurut Winters mayoritas oligarki Indonesia telah mengalahkan sistem demokrasi. Winters dalam hasil riset yang ia lakukan, menunjukkan ketimpangan kekayaan di Indonesia jauh lebih merata antara kelompok kaya dengan kelompok miskin saat tahun 1945 jika dibandingkan saat ini. Richard Robison serta Vedi R. Hadiz (20014:12) di dalam bukunya yang berjudul "Reorganizing Power in Indonesia: The Politics of Oligarchy in an Age of Market" memperkuat pernyataan Winters. Buku tersebut menjelaskan oligarki di Indonesia tidak hilang begitu saja pasca reformasi. Oligarki justru terus bertransformasi dengan cara menyesuaikan konteks politik di Indonesia. Menurutnya, hal tersebut di dorong oleh Neoliberalisme.

Kekuatan ekonomi di zaman Orde Baru menguasai demokratisasi, mengharuskan kaum oligarki harus terlibat dalam partai politik bahkan menjadi petinggi. Dunia politik melalui jabatan yang diduduki seolah menjadi akses melancarkan misinya untuk mempertahankan kekayaan secara langsung. Menurut Winters dan Robinso oligarki tidak hilang begitu saja, ia hanya menjelma 
dalam jenis yang berbeda. Oligarki yang semula bersifat oligarki sultanistik pada era pemerintahan Soeharto, kini bertransformasi menjadi oligarki penguasa kolektif. Para penguasa saling bekerja sama dalam mempertahankan kekayaannya, dengan masuk ke dalam jabatan politik untuk mendapatkan otoritas.

Kasus Penambangan batubara di Kalimantan Timur memiliki kesamaan dengan pernyataan di atas. Film Sexy Killers menunjukkan fakta empiris yang terjadi di lapangan. Para pemain tambang batubara di Kalimantan menunjukan adanya indikasi oligarki. Film Sexy Killers memperlihatkan bagaimana sistem demokrasi dikalahkan dengan kekuasaan. Kekuasaan tersebut digunakan untuk melancarkan misi bisnis atas proyek penambangan batubara.

Teori Winters membantu membuktikan pernyataan di atas. Pertama, Teori yang menyatakan bahwa oligarki dapat dilihat dengan ciri dasar kekuasaan minoritas oligarki. Minoritas didasarkan kepada konsentrasi ekstrem kekuasaan dan dibuyarkan dengan pemecahan kekuasaan secara radikal. Pada Film Sexy Killers menyuguhkan alur bagan yang jelas pemain batubara di dalamnya. Meski terlihat sebagai individu atau kubu yang saling bersaing di ranah politisi, namun sejatinya mereka terhubung antar satu sama lainnya. Hubungan dengan latar belakang tujuan yang sama, yaitu misi bisnis. Otoritas yang dimiliki seolah menjadi alat untuk membungkam jejak aksi dalam proyek tambang batubara di Kalimantan Timur. Otoritas tersebut mampu membuat jajaran pemerintah dibawahnya tidak bisa melawan kendali, sehingga kekuasaanpun semakin kuat mengeruk sumber daya di Kalimantan Timur.

Kedua, melihat jangkauan kekuasaan minoritas oligarki. Jangkauan kekuasaan minoritas oligarki merengkuh komunitas cukup luas sehingga usaha melarikan diri darinya nyaris mustahil dan mahal sekali biayanya. Kasusnya pada film ketika Nyoman mencoba protes namun dirinya justru terjerat dalam hukum atas vonis menganggu operasional perusahaan. Nyoman menjelaskan bahwa di era Soeharto, pemerintah yang telah membawanya ke Kalimantan Timur untuk tinggal dan bercocok tanam. Saat ini, justru pemerintah juga yang menghancurkan mata pencariannya dengan mengizinkan perusahaan terus mengexploitasi tempat tinggal dan perkebenunan miliknya (Sexy Killers 2019, menit ke 9:44). Nyoman dan masyarakat Kutai Kartanegara tidak memiliki pilihan karena tidak dapat bergantung dan meluapkan aspirasi pada mereka yang sudah semestinya mengayomi. Sangat mustahil bagi Nyoman dan masyarakat Kutai Kartanegara juga untuk melawan, karena hak suara telah dikalahkan pada radikalnya kekuasaan yang telah tersebar. Ketidakberdayaan Nyoman dan masyarakat Kutai Kartanegara membuatnya sangat sulit untuk melarikan diri. Lingkaran oligarki membuat Nyoman dan masyarakat harus rela menelan kenyataan pahit meski telah dijajahi bertahun-tahun lamanya. Jika mereka ingin keluar dari lingkaran oligarki, Nyoman dan masyarakat Kutai Kartanegara harus rela hak miliknya diambil dan mulai menata kehidupan kembali untuk pindah ke daerah lainnya. Namun, implementasi tidak akan semudah angan. Sesuai pada teori yang dijelaskan pada Winters, implementasi ini akan membutuhkan biaya yang sangat mahal.

\subsection{Elite dalam Lingkaran Oligarki}

Pada tahun 2019 Indonesia merayakan pesta demokrasi dengan memilih dua kubu kandidat presiden dan wakil presiden yaitu Jokowi-Amin dan Prabowo-Sandi Uno. Film Sexy Killers justru membuat geger dengan menyuguhkan penemuan alur keterlibatan dua kubu tersebut dalam operasional tambang batu bara di Kalimantan Timur. Keterlibatan dua kubu capres dan cawapres 2019 semakin hangat lagi disoroti mengingat dampaknya yang telah merenggut banyak korban jiwa. Film Sexy Killers juga menyeret beberapa tokoh politik di Indonesia. Tokoh- tokoh yang telah disebutkan diduga terjerat dalam lingkaran oligarki.

Beberapa nama pemain dari kedua kubu Jokowi-Amin dan Prabowo-Sandiaga uno disuguhkan. Pada kubu jokowi amin yang terkait langsung degan bisnis tambang dan energi yang tergabung dalam tim bravo 5 yakni Luhut Binsar Panjaitan, Fachrul Razi, dan Saudi Marambessy. Selain 
mereka, juga disebutkan nama lain seperti Hary Tanaoesoedibjo, Surya Paloh, Sakti Wahyu Trenggono, Jusuf Kala, Andi Syamsudin Arsyad, dan Oesman Sapta Oedang.

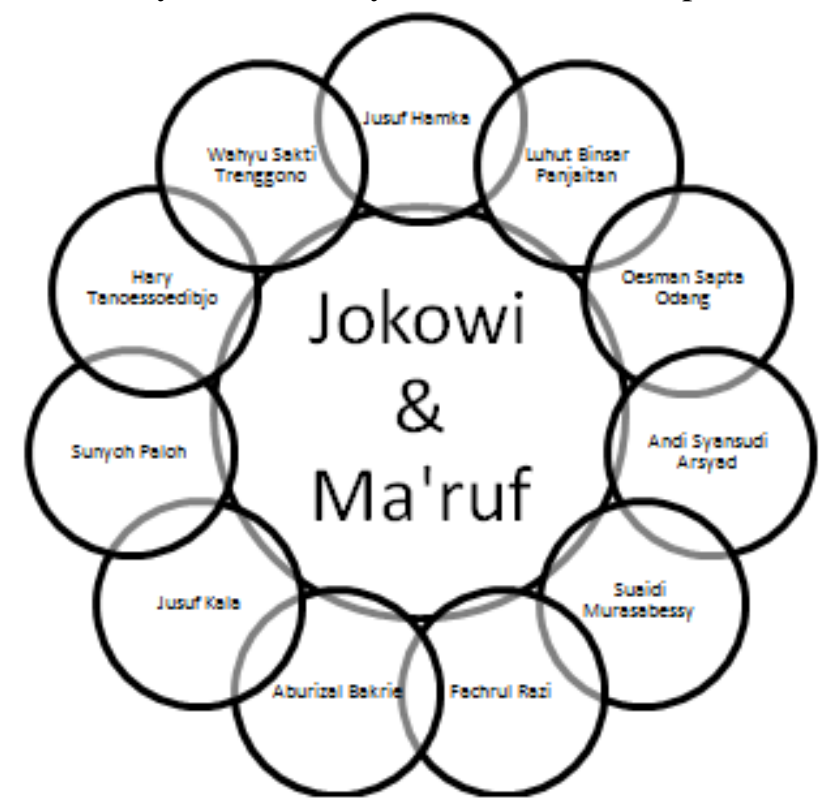

Gambar 1. Pemain Batu Bara dari Kubu Jokowi- Ma'ruf Amin

Sumber: Film Sexy Killers, data diolah Tahun 2020.

Tak kalah menarik, kubu Prabowo-Sandiaga Uno pun disuguhkan. Lebih gamblang lagi adalah ketika Prabowo dan Sandiaga Uno diketahui merupakan pemain lama sektor tambang dan energi. Selain mereka beberapa nama juga disebutkan seperti Hutomo Mandala Putra atau Tommy Suharto, Maher AlGadrie, Hashim Djojohadikusumo, Sudirman Said, Ferry Mursyadan Baldan dan Zulkifli Hasan. Hal ini menjadi semakin menarik ketika PT Saratoga Investama milik Sandiaga Uno telah melepas sebagian sahamnya sebesar 130 Milyar kepada perusahaan PT Toba Bara milik Luhut Binsar Panajaitan.

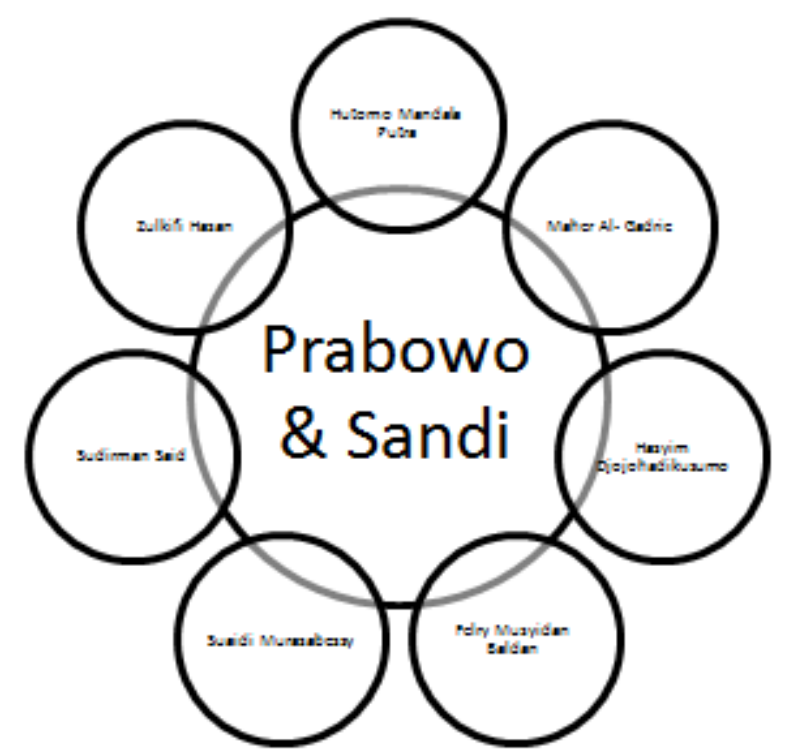

Gambar 2. Pemain Batu Bara dari Kubu Prabowo-Sandi Sumber: Film Sexy Killers, data diolah Tahun 2020. 
Laporan jaringan advokasi tambang 4 (JATAM) menjelaskan perusahaan keluarga Luhut Binsar Panjaitan setidaknya memiliki 50 lubang tambang di dalamnya. Masing-masing dimiliki oleh anak perusahaan PT Toba Bara Sejahtera yaitu PT Adimitra Baratama Nusantara sebanyak 13 lokasi lubang, PT Trisensa Mineral Utama sebanyak 14 lokasi lubang, PT Indomining memiliki sebanyak 14 lokasi lubang, dan juga PT Kutai Energi sebanyak 9 lubang tambang batu bara. Sehingga total lahan konsensi yang dikuasai oleh perusahaan yang terafisiliasi dengan menteri kordinator kemaritiman di kabinet presiden Jokowi periode 2014-2024 adalah sebanyak 14 ribu hektar (JATAM dalam Sexy Killers 2019, menit ke 22:40). PT Toba Bara pada akhirnya memiliki usaha dari hulu ke hilir dari tambang batu baraa sampai pada pemilik saham PLTU di beberapa daerah. Grup Toba Sejahtera terbagi ke dalam 6 anak usaha yang terdiri dari Toba Coal dand Mining, Toba Oil and Gas, Toba Power, Toba Perkebunan dan Kehutanan, Toba Industri dan Toba Property and Infrrastucture. Keenam anak usaha tersebut kemudian terbagi lagi menjadi 16 perusahaan yang bergerak di berbagai

sektor.

Sandiago uno juga memiliki perusahaan PT Multi Harapan Utama, PT Saratoga Investama dan PT Adaro Energi dimana sebagian saham Adaro Energi juga dimiliki oleh adik kandung Erick Tohir selaku ketua tim pemenangan kubu Jokowi. Selain itu adik kandung Prabowo Subianto memiliki saham di PT Batu Hitam Perkasa dan sejumlah perusahaan lainnya. Kelurga ini merupakan pemain lama batu bara.

Hal tersebut jika dilihat dalam kacamata oligarki Winters, telah memasuki lingkaran paling fatal. Pemerintah yang sudah seharusnya mampu mengendalikan perilaku oligarki dengan menerapkan sistem yang tegas justru akan ikut terbawa arus lingkaran oligarki. Meskipun dipanggung politik tokoh politik tersebut seolah menawarkan jargon diferensiasi jargon-jargon kerakyatan, Sexy Killers menyuguhkan alur bagan yang jelas pemain batubara di dalamnya. Siapa berhubungan dengan siapa dan siapa saja yang bekerjasama di dalamnya.

Hal ini memperlihatkan bahwa elite penguasa bermain sebagai oligarkh melalui otoritas kekuasaan. Para pemangku kekuasaan saling terhubung dan bekerjasama satu sama lain untuk melancarkan misi bisnis. Jika oligarki masih terus terjadi, maka sistem demokrasi akan semakin terkikis. Kesejahteraan rakyat hanya akan menjadi angan, karena sumber daya alam hanya akan terkeruk habis untuk kesejahteraan para oligarkh yang berkuasa.

\section{KESIMPULAN}

Oligarki dipahami sebagai lingkaran kekuasaan yang menggunakan otoritas kekuasaanya untuk misi bisnis segelintir elite. Berbagai potret memperlihatkan bahwa oligarki akan berdampak pada kerugian. Dampak yang paling terlihat akibat oligarki yaitu adanya kesenjangan antara kelas sosial. Teori oligarki Winters mampu membuktikan kasus tambang batu bara di Kalimantan Timur memiliki indikasi lingkaran oligarki di dalamnya. Sexy Killers menjadi fakta empiris melalui alur bagan yang jelas pemain batubara di dalamnya. Siapa berhubungan dengan siapa dan siapa saja yang bekerjasama di dalamnya. Para penguasa saling bekerja sama dalam mempertahankan kekayaannya dengan masuk ke dalam suatu komunitas jabatan yang memiliki otoritas. Melalui otoritas, para elite mengendalikan sumber daya material untuk meningkatkan kekayaan dan mempertahankan posisi sosialnya. Oligarki yang terlihat pada era Soeharto ternyata tidak lantas menghilang begitu saja. Oligarki justru berkembang dengan wujud yang berbeda. Oligarki saat pemerintahan Soeharto bersifat oligarki sultanisti dan saat ini bertransformasi menjadi oligarki penguasa kolektif. 


\section{SARAN}

Oligarki seolah sulit dihilangkan. Berikut beberapa hal yang dapat dilakukan agar dapat meminimalisir lingkaran oligarki. Pertama, diperlukan adanya political will dari para elite politik. Pemerintah pusat dan daerah harus memiliki kemauan kuat untuk menyelesaikan permasalahan yang ada. Hal ini dapat dilakukan jika pemerintah tidak terjebak dalam lingkaran elite oligarki kekuasaan pebisnis batubara. Konflik kepentingan akan sulit dihindarkan jika pemerintah masih terjebak sebagai pelaku bisnis itu sendiri.

Kedua, ketegasan hukum. Potret penetapan minimal jarak sebanyak 500M yang tidak diindahkan melalui Peraturan Daerah Kabupaten Kutai Kartanegara nomer 79 Tahun 2013 memperlihatkan payung hukum yang mudah diabaikan begitu saja. Para penegak hukum harus memiliki komitmen untuk bersikap tegas menjalankan tegaknya keadilan tanpa tebang pilih. Jika penegak hukum bersikap tajam ke bawah tapi tumpul keatas, maka keadilan akan sulit untuk ditegakkan. Hal ini memerlukan komitmen dari para penegak hukum untuk menjaga marwah hukum melalui tegaknya keadilan.

Ketiga, kontrol sosial harus dilakukan secara massif. Pers harus mengawal melalui produk jurnalistik. Para akademisi harus terlibat melalui riset dan diskusi-diskusi terkait permasalahan tersebut. Masyarakat juga harus ikut mengawal secara aktif progresif.

\section{DAFTAR PUSTAKA}

\section{Buku:}

[1] Robison, Richard and Vedi R Hadiz. 2004. Reorganizing Power in Indonesia: The Politics of Oligarchy in an Age of Market. London and New York: Routledge.

[2] Winters, Jeffrey A. 2011. Oligarki terj. Jakarta: Gramedia Pustaka Utama.

[3] Siti Airinda Marennu. 2019. Analisis Kebijakan Pemerintah Daerah Bidang Pertambangan di Kota Samarinda. Jurnal Ilmu Pemerintahan: 12(1) 21-32.

[4] Muhamad Muhdar. 2015. Aspek Hukum Reklamasi Pertambangan Batu Bara Pada Kawasan Hutan di Kalimantan Timur. Jurnal Hukum : 27(3) 472-486.

[5] Dicky Dwi Ananta. 2014. Politik Oligarki dan Perampasan Tanah di Indonesia: Kasus Perampasan Tanah di Kabupaten Karawang Tahun 2014. Jurnal politik: 2(1): 101-135.

[6] Husen Zuada dkk. 2016. Otonomi Daerah dan Pembangunan Pedesaan. Jurnal Politik: 13(2):137-275.

[7] Istiadi. 2017. Kebijakan Penetapan Kuota Produuksi Batubara: Analisis dan Penerapannya di Dinas pertambangan dan Energi Provinsi Kalimantan Timur. Jurnal Paradigma: 6(2):99-107.

[8] Hidayat dkk. 2016. Praktik Politik Oligarki dan Mobilisasi Sumber Daya Kekuasaan Di Pilkades Desa Sitimerto Pada Tahun 2016. Jurnal sospol : 4(2) 124-151

Film :

[9] Sexy Killers. 2019. Rumah produksi Wathdoc 


\section{Undang-Undang :}

[10] Peraturan Bupati Kutai Kartanegara No 79 Tahun 2016 Tentang Pedoman Pengelolaan Lingkungan Hidup Bagi Usaha Kegiatan Operasi produksi Batubara Secara Terbuka dan Fasilitas Penunjanganya.

\section{Internet}

[11] Kompas.

2019.

Cadangan

batubara

Indonesia,

https://money.kompas.com/read/2019/07/28/133500626/cadangan-batu-bara-indonesiatinggal-80-tahun-lagi-, diakses tanggal 09 Maret 2020

[12] Badan Tenaga Nuklir Nasional (BATAN). 2018. Pertimbangan Kebutuhan Batubara, http://www.batan.go.id. diakses tanggal 09 Maret 2020. 